\title{
Abordaje minipretemporal transtentorial Trans-Meckel con petrosectomía anterior para Schwannoma del trigémino
}

\section{Mini-Pretemporal Trans-Meckel's cave transtentorial approach with anterior petrosectomy for Trigeminal Schwannoma}

\section{Víctor Hernández-Álvarez¹, Aladino Rojas-Cárdenas}

${ }^{1}$ Neurocirujano vascular y de la base del cráneo. Hospital Barros Luco Trudeau. Universidad de Santiago de Chile.

\section{Resumen}

Los Schwannomas del trigémino son tumores benignos de baja frecuencia, correspondiendo al $4 \%$ de los tumores intracraneales, a diferencia de los schwannomas vestibulares que se ven entre un 8 a $10 \%$. Estos tumores pueden afectar a la fosa craneal media, a la fosa posterior o ambas, lo que se conoce como en forma de mancuerna. Presentamos a un paciente de sexo femenino, de 54 años, con antecedentes de hipotiroidismo, HTA y aneurisma de arteria comunicante anterior embolizado con clínica de hipoestesia de V1, V2 y V3 derecho, más atrofia del masetero. Con diagnóstico imagenólogico de Schwannoma del trigémino derecho, manteniéndose en control con resonancia magnética cerebral en donde se percata un aumento del crecimiento tumoral, por lo que se indica cirugía. En este video mostramos el análisis en cuanto a imagen pre operatoria, el detalle quirúrgico de la microcirugía realizada y el resultado post operatorio, enfatizando la vía mipretemporal como un acceso seguro para este tipo de patologías sin la necesidad de la resección del cigoma.

Palabras clave: Trigeminal schwannoma, microsurgery, video.

\section{Abstract}

Trigeminal Schwannoma are low frequency benign tumors, corresponding to $4 \%$ of intracranial tumors, unlike vestibular schwannomas, which are seen between 8 and $10 \%$. These tumors can affect the middle cranial fossa, the posterior fossa, or both, which is known as dumbbell-shaped. We present a 54-year-old female patient with a history of hypothyroidism, hypertension and embolized anterior communicating artery aneurysm with symptoms of right V1, V2 and V3 hypoesthesia, plus masseter atrophy. With an imaging diagnosis of right Trigeminal Schwannoma, keeping in control with brain Magnetic Resonance where an increase in tumor growth is noticed, for which surgery is indicated. In this video we show the analysis regarding the pre-operative image, the surgical detail of the microsurgery performed and the post-operative result, emphasizing the Mini-pretemporal route as a safe access for this type of pathology without the need for resection of the zygoma.

Key words: Trigeminal schwannoma, microsurgery, video. 